\title{
Editorial: Greenhouse gases in animal agriculture: science supporting practices
}

\author{
A. Berndt ${ }^{1 t a} \oplus$, A. L. Abdalla ${ }^{2} \odot$ and L. G. R. Pereira ${ }^{3} \odot$ \\ ${ }^{1}$ Brazilian Agricultural Research Corporation (Embrapa Southeast Livestock), Rod. Washington Luiz, km234, CP339, São Carlos, São Paulo 13560-970, Brazil, ${ }^{2}$ University \\ of São Paulo (CENA-USP), Av. Centenário, 303 - São Dimas, Piracicaba, São Paulo 13416-000, Brazil; ${ }^{3}$ Brazilian Agricultural Research Corporation (Embrapa Dairy Cattle), \\ Av. Eugênio do Nascimento, 610, Aeroporto, Juiz de Fora, Minas Gerais 36038-330, Brazil
}

The populational growth, the increase of demand for livestock product, the technological progress, the changes in income distribution, concerns related to climate change and environment have been driving the scientific community to develop knowledge regarding sustainable animal agriculture. Climate change represents a significant threat, with an estimated increase of the average global temperature at the end of the 21st century (compared with 1980 to 1999) between $1.8^{\circ} \mathrm{C}$ (B1 scenario) and $4.0^{\circ} \mathrm{C}$ (A1Fl scenario) (IPCC, 2007). This shift in temperature represents a direct and indirect impact on agriculture systems as well as on human and animal health. Animal agriculture sustainable production systems can present key solutions in a changing climate, at the same time as reducing its impact so as not to aggravate it further (Gaughan et al., 2019).

In this context, the Greenhouse Gas and Animal Agriculture Conference (GGAA) is the premier international conference summarizing the collective state of scientific knowledge on greenhouse gas abatement strategies and production systems adaptation needs for the livestock sector. This gathering features leading scientists and policymakers reviewing the current state of knowledge and presenting significant new developments in policy, measurement, modelling, mitigation and adaptation efforts associated with greenhouse gases from animal agriculture.

The Conference took place every 2 years in the first three editions and every 3 years since 2010 when the main abstracts were published as full article in special issues of peer-reviewed journals (McAllister et al., 2011; Dewhurst, 2013; Eckard, 2016). Finally, GGAA2019 happened for the first time in Latin America, which focused on the theme 'Science supporting Practices'.

aPresent address: EMBRAPA Southeast Livestock, Rod. Washington Luiz, km 234, CP339, São Carlos, São Paulo 13560-970, Brazil.

${ }^{\dagger}$ E-mail: alexandre.berndt@embrapa.br
At the GGAA2019 conference, held in Iguassu Falls, Brazil, almost 200 delegates from 39 countries gathered to participate in a program featuring 11 invited keynote speakers, 47 offered presentations and 111 poster presentations. Of the 158 papers presented at the Iguassu Falls, 7 were selected and survived critical review and are in this Special Issue. The $7^{\text {th }}$ meeting in the series was organized in Brazil in August 2019, jointly by Brazilian Agricultural Research Corporation-Embrapa, University of São Paulo-USP, São Paulo State University-UNESP, Instituto de Investigaciones Agropecuarias - INIA/Chile and Instituto Nacional de Tecnología Agropecuaria-INTA/Argentina.

Despite the fact that the countries located in the tropical belt of the Earth are important players for worldwide food production, there were gaps related to carbon balance and specific models for enteric methane predictions in tropical livestock production systems as pointed in GGAA 2013 by Berndt and Tomkins (2013). This Special Issue addresses these gaps in the Oliveira et al (2020) paper that showed the effects of intensification of tropical pastures on carbon balance and by Ribeiro et al. (2020) that compiled a database of $\mathrm{CH}_{4}$ emissions to evaluate prediction precision and accuracy of extant equations and to develop novel equations for predicting enteric methane emissions from cattle in tropical conditions. Furthermore, Ku-Vera et al. (2020) reviewed the strategies for enteric methane mitigation in cattle fed lowquality tropical forages.

During the GGAA meetings, it was possible to observe the increase in options for dietary strategies with the potential to mitigate enteric methane, with emphasis on the use of vegetable oils (Ludemann et al., 2016), secondary compounds (Samal et al., 2016), nitrate (Guyader et al., 2016) and 3nitrooxypropanol evidenced by the 10 papers published in GGAA2019 (Berndt et al. 2019). In this special edition, Williams et al. (2020) showed the positive effects of the association of fat or tannin to reduce methane yield in dairy cattle. 
There has been growing interest in the potential to breed ruminants for reduced $\mathrm{CH}_{4}$ emissions and Lassen and Difford (2020) discussed the genetic and genomic selection as a methane mitigation strategy in dairy cattle. Regarding the advances in techniques to measure enteric $\mathrm{CH}_{4}$, Hristov and Melgar (2020) demonstrated that the relationship of enteric methane emission measured using Green Feed and Dry Mater Intake in dairy cows depends on the time of measurement relative to the time of feeding. Therefore, a sufficient number of gas samples, covering the entire 24-h feeding cycle, have to be collected to have representative emission estimates using the green feed system.

Finally, the review 'Climate Finance and the Livestock Sector' by Masse and Gerber (2020) showed the challenges and opportunities to encourage sustainable livestock practices.

A special word of thanks is due to the guests editing the papers in this Special Issue. They are $\operatorname{Dr}$ Karen $A$. Beauchemin, Dr Patricia Ricci and Dr Tim McAllister.

\section{Acknowledgements}

The Local Organizing Committee is comprised of Dr Alexandre Berndt (Embrapa Southeast Livestock), Dr Luiz Gustavo R. Pereira (Embrapa Dairy Cattle), Dr Adibe Luis Abdalla (CENA/USP), Dr Marta Alfaro Valenzuela (INIA), Dr Jose Ignacio Arroquy (INTA), Dr Telma Teresinha Berchielli (UNESP) and Dr Julio Palhares (Embrapa Southeast Livestock).

Financial assistance to the '7st Greenhouse gases in animal agriculture conference' by the sponsors listed alphabetically below is gratefully acknowledged: Associação Rede ILPF, Bioprocess Control AB., C-Lock Inc., DSM, Global Research Alliance on Agricultural Greenhouse Gases, National Council for Scientific and Technological Development-CNPq, New Zealand Agricultural Greenhouse Gas Research Centre.

D A. Berndt 0000-0002-8976-2399

A. L. Abdalla 0000-0002-5440-9974

L. G. R. Pereira 0000-0001-7166-5817

\section{Declaration of interest}

Not applicable.

\section{Ethics statement \\ Not applicable.}

\section{Software and data repository resources Not applicable.}

\section{References}

Berndt A, Pereira LGR, Abdalla AL 2019. Proceedings of the 7th International Greenhouse Gas and Animal Agriculture. Retrieved on 23 June 2020 from http://ainfo.cnptia.embrapa.br/digital/bitstream/item/206280/1/Greenhouse GasAnimal.pdf

Berndt A and Tomkins NW 2013. Measurement and mitigation of methane emissions from beef cattle in tropical grazing systems: a perspective from Australia and Brazil. Animal 7 (suppl. 2), 363-372.

Dewhurst RJ 2013. Editorial: Greenhouse Gases and Animal Agriculture Conference, Dublin, 2013. Animal 7 (suppl. 2), 203-205.

Eckard R 2016. Foreword: GGAA2016 Special Edition. Animal Production Science 56, iii.

Gaughan JB, Sejian V, Mader TL and Dunshea FR 2019. Adaptation strategies: ruminants. Animal Frontiers 9, 47-53.

Guyader J, Tavendale M, Martin C and Muetzel S 2016. Dose-response effect of nitrate on hydrogen distribution between rumen fermentation end products: an in vitro approach. Animal Production Science 56, 224.

Hristov A and Melgar A 2020. Short communication: Relationship of dry matter intake with enteric methane emission measured with the GreenFeed system in dairy cows receiving a diet without or with 3-nitrooxypropanol. Animal 14, s484-s490.

IPCC 2007. Climate Change 2007: The Physical Science Basis. In Contribution of Working Group I to the Fourth Assessment Report of the Intergovernmental Panel on Climate Change. Cambridge University Press, Cambridge, United Kingdom and New York, NY, USA.

Ku-Vera JC, Castelán-Ortega OA, Galindo-Maldonado FA, Arango J, Chirinda N, Jiménez-Ocampo R, Valencia-Salazar SS, Flores-Santiago EJ, Montoya-Flores MD, Molina-Botero IC, Piñeiro-Vázquez AT, Arceo-Castillo Jl, Aguilar-Pérez CF, Ramírez-Avilés L, Solorio-Sánchez FJ 2020. Review: Strategies for enteric methane mitigation in cattle fed tropical forages. Animal 14, s453-s463.

Lassen J and Difford GF 2020. Review: Genetic and genomic selection as a methane mitigation strategy in dairy cattle. Animal 14, s473-s483.

Ludemann $\mathrm{Cl}$, Howden SM and Eckard RJ 2016. What is the best use of oil from cotton (Gossypium spp.) and canola (Brassica spp.) for reducing net greenhouse gas emissions: biodiesel, or as a feed for cattle? Animal Production Science $56,442$.

Masse J and Gerber P 2020. Review: Climate Finance readiness of the animal protein sector. Overview of experience in linking the sector to climate finance, and options to address bottlenecks. Animal 14, s491-s499.

McAllister TA, Beauchemin KA, McGinn SM, Hao X and Robinson PH 2011. Greenhouse gases in animal agriculture-Finding a balance between food production and emissions. Animal Feed Science and Technology 166-167, 1-6.

Oliveira PPA, Berndt A, Pedroso AF, Alves TC, Pezzopane JRM, Sakamoto LS, Henrique FL, Rodrigues PM 2020. Greenhouse gas balance and carbon footprint of pasture-based beef cattle production systems in the tropical region (Atlantic Forest biome). Animal 14, s427-s437.

Ribeiro RS, Rodrigues JPP, Mauricio RM, Borges ALCC, Berchielli TT, Valadares Filho SC, Machado FS, Campos, MM, Tomich, TR, Pereira, LGR 2020. Predicting enteric methane production from cattle in the tropics. Animal 14, s438-s452.

Samal L, Chaudhary LC, Agarwal N and Kamra DN 2016. Effects of plants containing secondary metabolites as feed additives on rumen metabolites and methanogen diversity of buffaloes. Animal Production Science 56, 472.

Williams SRO, Hannah MC, Eckard RJ, Wales WJ and Moate PJ 2020. Supplementing the diet of dairy cows with fat or tannin reduces methane yield, and additively when fed in combination. Animal 14, s464-s472. 